\title{
APLIKASI SISTEM PAKAR PUSAT INFORMASI KONSELING REMAJA (PIK-R) DI SMAN 2 DUMAI DENGAN METODE BACKWARD CHAINING MENGGUNAKAN BAHASA PEMOGRAMAN PHP
}

\author{
Ahmad Fadel ${ }^{1}$, Mardayulis ${ }^{2}$, Putri Yunita ${ }^{3}$ \\ ${ }^{1,3}$ Sekolah Tinggi Manajemen Informatika \& Komputer (STMIK) Dumai \\ ${ }^{2}$ Akademi Manajemen Informatika \& Komputer (AMIK) Dumai \\ 1,2,3 Jl. Utama Karya Bukit Batrem Dumai Kode Pos 28811 \\ e-mail : ahmadfadel2306@gmail.com
}

\begin{abstract}
ABSTRAK
PIK-R adalah suatu organisasi yang berperan sebagai wadah konseling setiap permasalahan yang dialami siswa dan siswi SMAN 2 Dumai. Dimana permasalahan yang dijadikan dasar dalam penulisan ini adalah Proses Konseling yamg dilakukan oleh guru BK dan Organisasi PIK-R kerap tidak efesien terhadap penanganan masalah-masalah yang ada pada siswa dan siswi SMAN 2 Dumai. Pada prosesnya sering kali konseling dilakukan pada saat jam pelajaran. Maka dari itu penelitian ini membuat suatu aplikasi pusat konseling berbasis web sehingga siswa dapat melakukan konseling dimana saja dan kapan saja dan juga penelitian ini mengunakan metode Backward Chaining maka dapat langsung mendiagnosa permasalahan apa yang di alami siswa dan siswi SMAN 2 Dumai dan bertujuan agar lebih efektifnya suatu proses konseling dalam penanganan masalah-masalah siswa dan siswi SMAN 2 Dumai dan menjadikan penerapan pendidikan berbasis karakter yang tepat sasaran.
\end{abstract}

Kata kunci : konseling, sistem pakar, php, Backward chaining

\section{PENDAHULUAN}

SMAN 2 Dumai adalah salah satu sekolah menenggah atas unggulan yang ada di kota Dumai yang di mana sekolah ini merupakan sekolah yang menerapkan sistem pendidikan berbasis karakter. Yang bertujuan untuk mendidik siswa siswi supaya memiliki kepribadian yang baik, sehingga menciptakan lulusan yang berguna bagi bangsa ini.

Adapun untuk membanggun suatu generasi yang berkualitas, sekolah tidaklah hanya mengedepankan nilai yang di dapat dalam proses pembelajaran dikelas, akan tetapi diperlukanya pendidikan untuk membangun karakter yang baik bagi siswa dan siswi tersebut, maka dari itu SMAN 2 membuat suatu organisasi Pusat Informasi Konseling Remaja (PIK-R), di dalam organisasi tersebut memiliki fungsi untuk membantu berbagai masalah kepribadian menyimpang yang dihadapi oleh siswa dan siswi SMAN 2 Dumai baik di dalam lingkungan sekolah maupun di luar lingkungan sekolah.
Keputusan peneyelesaian masalah yang akan diberi atas masalah-masalah kepribadian yang di alami oleh siswa dan siswi SMAN 2 Dumai dapat teratasi dengan efektif. Dengan memanfaatkan teknologi komputer dengan memberikan suatu wadah konseling, sehingga dapat memancing siswa dan siswi untuk bercerita tentang masalahnya, tentunya dengan membuat suatu aplikasi pada komputer yang dapat berkemampuan seperti seorang pakar yang akan dapat memberi suatu keputusan dan solusi atas masalah yang di alami. Maka dari itu peneliti mengunakan suatu aplikasi sistem pakar yang mengunakan metode Backward Chaining yang dimana, suatu metode yang menganalisa suatu masalah kepribadian menyimpang pada siswa maka siswa akan diberikan informasi berupa karakter-karakter yang menyebabkan kepribadian menyimpang tersebut terjadi, lalu siswa akan diberikan solusi atas karakterkarakter dari masalah kepribadian tersebut.

Tujuan dari penelitian ini adalah untuk mempelajarimetode backward, chaining dalam 


\section{INFORM T I K}

Jurnal Informatika, Manajemen dan Komputer, Vol. 10, No. 2, Desember 2018

eISSN : 2580-3042

pISSN : 1979-0694

menganalisa konseling dari setiap masalah yang ada pada siswa dan siswi SMAN 2 Dumai.

\section{a. Aplikasi}

Aplikasi komputer merupakan suatu perangkat lunak komputer yang memiliki fungsi tertentu sesuai dengan tujuan yang diinginkan oleh si pembuat aplikasi (programmer). Aplikasi komputer biasanya diciptakan untuk mempermudah manusia dalam mengerjakan suatu tugas didalam sebuah komputer, seperti untuk mengolah data maupun untuk keperluan editing.(Yunita, 2018)

\section{b. Metode Backward Chaining}

Backward Chaining adalah Penalaran berdasarkan tujuan (goal-driven), metode ini dimulai dengan membuat perkiraan dari apa yang akan terjadi, kemudian mencari fakta-fakta (evidence) yang mendukung (atau membantah) hipotesa tersebut. Backward chaining adalah suatu alasan yang berkebalikan dengan hypothesis, potensial konklusinya mungkin akan terjadi atau terbukti, karena adanya fakta yang mendukung akan hypothesis tersebut.

Dengan kata lain, prosesnya dimulai dari initial hyphotesis or goal (Hipotesa awal atau tujuan) melalui intermediet hipotheses or sub goals (hipotesa lanjutan atau bagian dari tujuan) yang akan memeriksa semua hipotesa yang ada apakah hipotesa itu benar atau salah sehingga akhirnya akan menuju suatu Evidence (fakta).

Sebagai contoh di urai sebagai berikut, jika suatu masalah mempunyai sederetan kaidah seperti tertulis dibawah ini:

\section{R1 : A and C, THEN E \\ R2 : IF D and C, THEN F \\ R3 : IF B and E, THEN F \\ R4 : IF B THEN C}

\section{R5 : IF F THEN G}

Dimana sebagai acuan diketahui bahwa fakta A dan B adalah true (benar) dan $\mathrm{G}$ adalah GOAL (tujuan). Berikut ini langkah-langkah yang digunakan dalam metode backward chaining:

1. Langkah 1 : mencari kebenaran dasar dari tujuan berdasarkan fakta yang ada, dimana sebagai acuannya kita sudah mengetahuinya.

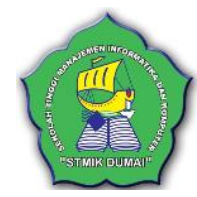

2. Langkah 2 : R5 menunjukkan bahwa jika $F$ benar maka $G$ benar. Untuk itu, maka kita akan melihat R2 dan R3.

3. Langkah 3 : R2 menunjukan bahwa $\mathrm{D}$ belum tentu benar sebab D tidak termasuk dalam fakta acuan, sehingga R2 tidak bisa digunakan, maka kita akan melihat ke kaidah yang lainnya yaitu kaidah R3.

4. Langkah 4 : pada kaidah R3, kita ketahui sesuai fakta acuan yang ada bahwa B adalah benar, selanjutnya kita akan melihat apakah E benar.

5. Langkah 5 : pada kaidah R1 sangat tergantung denga kebenaran $\mathrm{A}$ dan $\mathrm{C}$.

6. Langkah 6 : karena A diketahui sebagai fakta acuan adalah benar, selanjutnya kita akan melihat apakah $\mathrm{C}$ benar, dengan melihat R4.

7. Langkah $7: \mathrm{R} 4$ menunjukan bahwa $\mathrm{C}$ adalah benar karena B adalah benar. Dari langkah di atas dapat diambil kesimpulan bahwa $G$ adalah benar.(Nur, Ikhsan, Ariadi, Rosyid, \& Ridwan, 2017)

\section{c. Sistem Pakar}

sistem pakar adalah sistem yang berusaha mengadopsi pengetahuan manusia ke komputer yang dirancang untuk memodelkan kemampuan menyelesaikan masalah seperti layaknya seorang pakar. Dengan sistem pakar ini, orang awam pun dapat menyelesaikan masalahnya atau hanya sekedar mencari suatu informasi berkualitas yang sebenarnya hanya dapat diperoleh dengan bantuan para ahli di bidangnya.(Siti Mujilahwati, 2014)

\section{d. Bahasa Pemrograman PHP}

PHP adalah singkatan dari "PHP: Hypertext Preprocessor", yang merupakan sebuah bahasa scripting yang terpasang pada HTML untuk membuat webside yang dinamis. PHP ini merupakan server side scripting maksudnya sintak dan perintah-perintah PHP akan dieksekusi deserver kemudian hasilnya baru ditampilkan ke browser dalam format HTML, maka kode-kode yang kita tulis menggunkan PHP tidak akan kelihatan oleh user sehingga membuat halaman webside kita lebih aman dan dinamais.(Dahlan, 2013)

\section{e. Perancangan User Interface}

Rancangan arsitektur web secara keseluruhan dapat dilihat pada gambar di bawah ini. Gambar ini dibuat untuk menampilkan struktur dari halaman web yang akan direalisasikan.(Oktaviani, Widyawan, \& Hantono, 2014) 
I N F O R M A I I A

Jurnal Informatika, Manajemen dan Komputer, Vol. 10, No. 2, Desember 2018

eISSN : 2580-3042

pISSN : 1979-0694

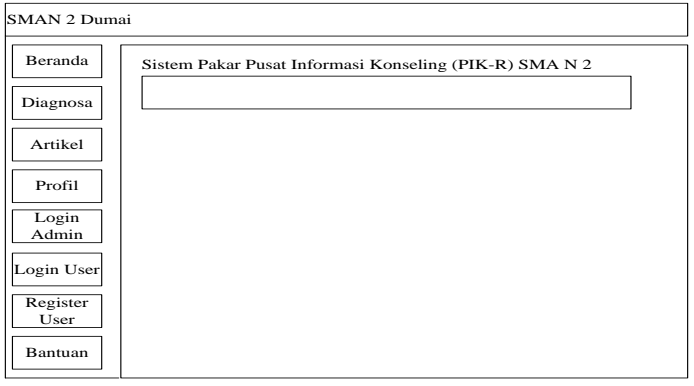

Gambar. 1. Interface navigation

\section{f. XАMPP}

XAMPP adalah software web server apache yang di dalamnya tertanam server MySQL yang didukung dengan bahasa pemrograman PHP untuk membuat website yang dinamis. XAMPP mendukung dua sistem operasi yaitu windows dan linux.(Noor \& Saw, 2016)

\section{g. Hasil Penelitian yang Relevan}

Untuk menghindari duplikasi, peneliti melakukan penelusuran terhadap penelitianpenelitian terdahulu. Dari hasil penelusuran penelitian, diperoleh beberapa masalah yang berkaitan dengan objek yang akan diteliti yaitu:

Aplikasi E-counseling Dalam Pemanfaatan Layanan Bimbingan dan Konseling Untuk Mengatasi Siwa Terisolir Menggunakan Metode Backward Chaining di SMP Negeri 2 Bangil, penelitian ini dilakukan oleh M. Noval Riswandha dan Nur Maulidyah, mahasiswa jurusan Teknik Informatika di Sekolah Tinggi Manajemen Informasi dan Komputer (STMIK), hasil penelitian terciptanya suatu aplikasi konseling berbasis web (e-counseling) sehingga dapat mempermudahnya siswa terisolir tersebut dalam melakukan konseling.(Riswandha \& Maulidyah, 2017)

\section{h. Sistem}

Suatu sistem adalah suatu jaringan kerja dari prosedur-prosedur yang berhubungan, berkumpul bersama-sama untuk melakukan suatu kegiatan atau untuk menyelesaikan suatu kegiatan atau untuk menyelesaikan suatu sasaran yang di tentukan.(Elisawati, 2017)

\section{METODOLOGI PENELITIAN}

\section{a. Kerangka Kerja}

Pembahasan dan penyelesaian penelitian ini dilakukan dengan mengikuti kerangka kerja berikut:
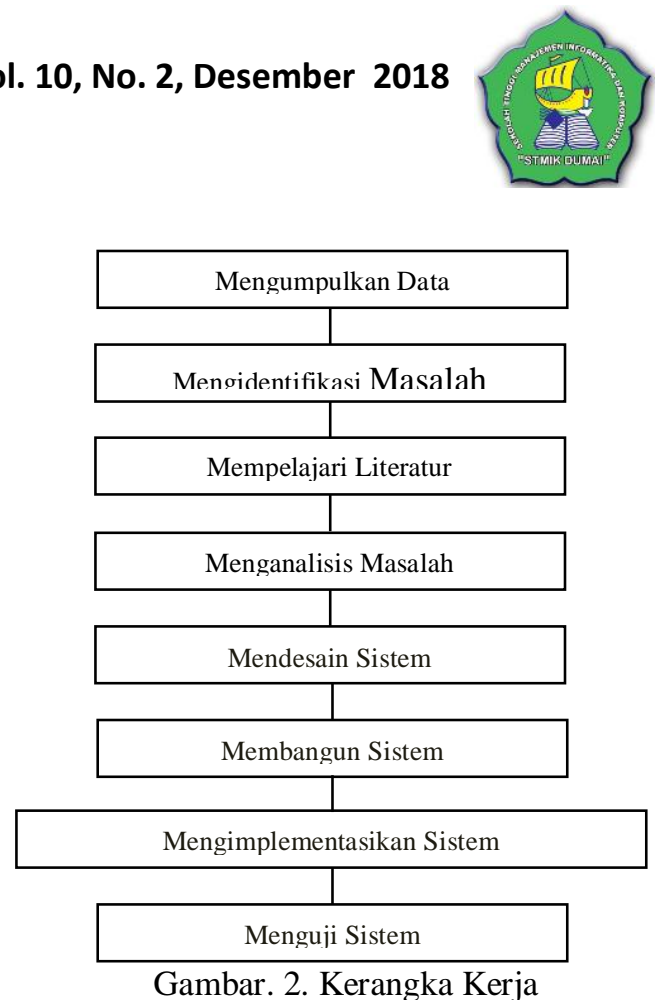

Berikut penjelasan dari gambar kerangka kerja di atas:

1. Mengumpulkan data

Pengumpulan data diambil dari berbagai sumber.

2. Mengidentifikasi masalah

Tahapan ini dimulai dengan melakukan survey kelapangan dan melihat secara langsung bagaimana proses konseling yang dilakukan guru BK dalam menyelesaikan masalahmasalah siswa SMAN 2 Dumai.

3. Mempelajari literature

Mempelajari jurnal-jurnal serta buku-buku yang berhubungan dengan permasalahan yang ada.

4. Menganalisis masalah

Analisis masalah pada penelitian ini mengunakan dua metode, yaitu metode deskriptif dimana pada metode ini data yang ada dikumpulkan, disusun, dikelompokan dan dianalisa sehingga diperoleh beberapa gambaran yang jelas pada permasalahan yang dibahas, dan penelitian ini juga menggunakan metode komperatif yaitu pada metode ini analisis dilakukan dengan cara membandingkan teori dan praktek, sehingga nantinya akan diperoleh gambaran yang jelas dalam pengimplementasian sistem.

5. Mendesain sistem

Pada tahap ini akan dilakukan proses desain sistem, dimulai dengan penyajian basis data berupa fakta dan aturan, desain antar muka masukan, pembuatan algoritma, dan pembuatan antar muka keluaran.

6. Membangun sistem 


\section{INFORM TIK}

Jurnal Informatika, Manajemen dan Komputer, Vol. 10, No. 2, Desember 2018

eISSN : 2580-3042

pISSN : 1979-0694

Membangun suatu sistem dengan melihat permasalahan yang ada maka dapat ditentukan kebutuhan-kebutuhan apa saja yang nantinya akan digunakan untuk proses Konseling.

7. Mengimplementasikan sistem

Pada tahap ini dilakukan pengkajian kembali kelayakan dari pada sistem yang telah dirancang, apakah sistem tersebut sudah sesuai atau masih perlu dilakukan peninjauan kembali atau penyempurnaan.

8. Menguji sistem

Pengujian hasil dilakukan dengan:

a. Melakukan pengolahan data dengan algoritma secara manual.

b. Melakukan pengujian data dengan menggunakan bahasa pemrograman PHP database MySQL berbasis web

c. Membandingkan pengujian data secara manual dengan hasil pengolahan data bahasa. Membandingkan hasil pengujian data secara manual dengan hasil pengolahan data mengunakan bahasa pemrograman PHP database MySQL berbasis web.

\section{HASIL DAN PEMBAHASAN}

\section{a. Analisis Sistem}

Penggunaan sistem informasi pada organisasi pusat informasi konseling remaja (PIK-R) SMAN 2 Dumai yang ada saat ini belum menggunakan pemanfaatan perkembangan teknologi. Oleh karena itu proses konseling masih berjalan dengan cara manual, sehingga pada proses konseling memerlukan waktu yang sangat lama dengan jumlah siswa yang banyak, di khawatirkan guru BK tidak dapat memberi layanan konseling untuk siswa siswi SMAN 2 Dumai yang memiliki kepribadian menyimpang.

\section{b. Analisis Kebutuhan Sistem}

Perancangan aplikasi pusat informasi konseling remaja (PIK-R) di SMAN 2 Dumai menggunakan metode backward chaining dengan bahasa pemrograman PHP, merupakan aplikasi yang digunakan untuk mengelola data konseling siswa dengan metode backward chaining. Data konseling ini juga meliputi pengelola input, proses, dan output. Input berupa data user, data pengguna, data karakter, data kepribadian, dan data solusi. Sistem juga harus dapat melakukan proses konseling dengan metode backward chaining.

Output yang diharapkan adalah memberi informasi tentang kepribadian pada siswa dan karakter-karakter yang menyebabkan kepribadian siswa menjadi buruk, serta dapat

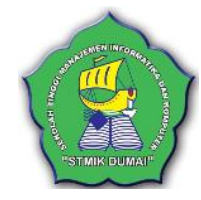

memberi solusi pada siswa terhadap kepribadian yang menyimpang tersebut. Dengan melakukan konseling dapat menghasilkan output dalam bentuk laporan hasil konseling yang dapat diajukan pada guru BK utuk melakukan konseling lanjut apabila hasil konseling tidak memuaskan atau tidak dapat dimengerti.

\section{c. Tahapan Konseptualisasi Perancangan Data}

Pada tahap ini peneliti akan menggambarkan sebuah konsep sistem yang akaan dirancang dari beberapa data yang di atas. Sehingga dapat menghasilkan sebuah output yang berupa konseling secara komputerisasi, dan laporan yang terdapat dari proses relasi antara beberapa tabel lalu akan ditentukan bobotnya dari setiap karakter sehingga diketahuilah kepribadian sisea tersebut.

Tahap konseptualisasi dilakukan perancangan data. Kerangka sistem masalah yang ada pada siswa dan siswi di SMAN 2 Dumai ditunjukan pada Gambar 3:

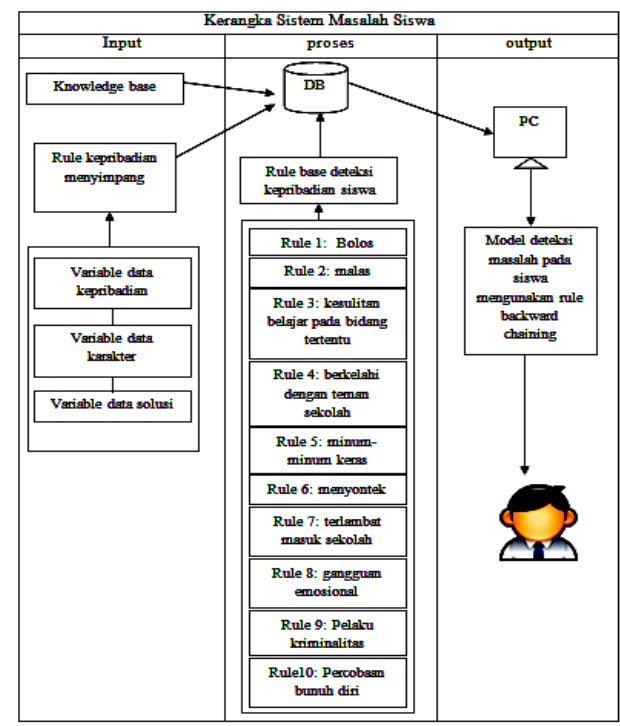

Gambar 3. Tahap Konseptualisasi

\section{d. Tahapan Formulasi Permodelan Backward Chaining}

Giarratano dan riley, 1994 menyatakan bahwa Backward Cahining merupakan salah satu model penalaran atau penelusuran dalam sistem pakar, dimana penalaran dimulai dengan tujuan kemudian merunut balik ke jalur yang akan mengarahkan ke tujuan tersebut.

Pohon keputusan menunjukan tipe penelusuran atau alur penelusuran dalam prose identifikas. Struktur pohon keputusan terdiri atas node-node yang menunjukkan objek dan arc (busur) yang menunjukan hubungan antar 
I N F O R M A I I A

Jurnal Informatika, Manajemen dan Komputer, Vol. 10, No. 2, Desember 2018

eISSN : 2580-3042

pISSN : 1979-0694

objek. Penelitian ini mengunakan model penelusuran backward chaining, dimana penalaran dimulai dari konsekuen ke anteseden. Metode ini bekerja secara backward untuk mendapatkan fakta-fakta yang mendukung hipotesa.

Dilakukan perancangan basis pengetahuan dengan membuat diagram alir aturan. Model penelusuran yang digunakan untuk mendeteksi karakter apa saja dan memberi solusi untuk sebuah kepribadian menyimpang pada siswa SMAN 2 Dumai adalah Backward Chaining. Dimana ilustrasi runut balik untuk fakta kepribadian ditunjukan pada gambar 3.2. Dimana seseorang akan menginput jenis kepribadian menyimpang lalu program akan memunculkan beberapa karekter dan solusi untuk masalah tersebut.

\begin{tabular}{|c|c|c|}
\hline Fakta & & Aturan \\
& & \multicolumn{1}{c|}{ Tujuan } \\
Kepribadia \\
n (P01) and \\
(S01), \\
(S02), \\
(S03), \\
(S04) \\
\end{tabular}

Gambar. 4. Ilustrasi runut balik fakta kepribadian

Node karakter kepribadian menyimpang siswa SMAN 2 Dumai ditandai dengan hurus K di mulai dari K01 sampai K35. Sementara jenis kepribadian yang akan dibahas dilambangkan dengan huruf $\mathrm{P}$ dan dimulai dari P01 sampai dengan P10. Rancangan pohon keputusan untuk identifikasi jenis masalah siswa SMAN 2 Dumai di tunjukan pada gambar 5. di bawah.

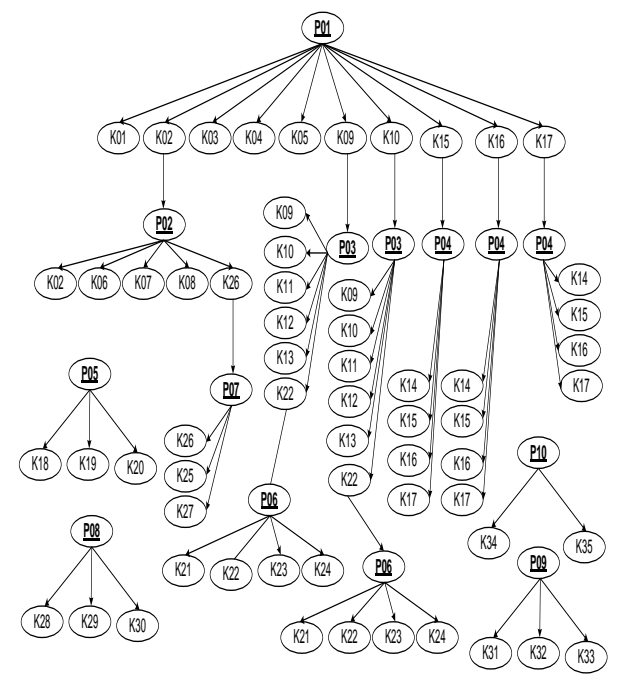

Gambar. 5. Pohon Pakar 
I N F O R M A T I K

Jurnal Informatika, Manajemen dan Komputer, Vol. 10, No. 2, Desember 2018

eISSN : 2580-3042

pISSN : 1979-0694

Model tersebut menggunakan logika and dimana jika pada tiap rule sudah terpenuhi karakter dari kepribadian tersebut. maka fungsi and akan menampilkan kepribadian atas karakter karakter yang dipilih, dan beserta solusi untuk setiap kepribadian yang menyimpang pada setiap rule yang di proses atas kepribadian yang sesuai, fakta kepribadian dan karakter beserta solusi yang di peroleh dari hasil penelitian yang di lakukan peneliti sesuai dengan apa yang di sampaikan oleh guru BK dan kondisi kepribadian siswa dan siswi di SMAN 2 Dumai.

\section{Context Diagram}

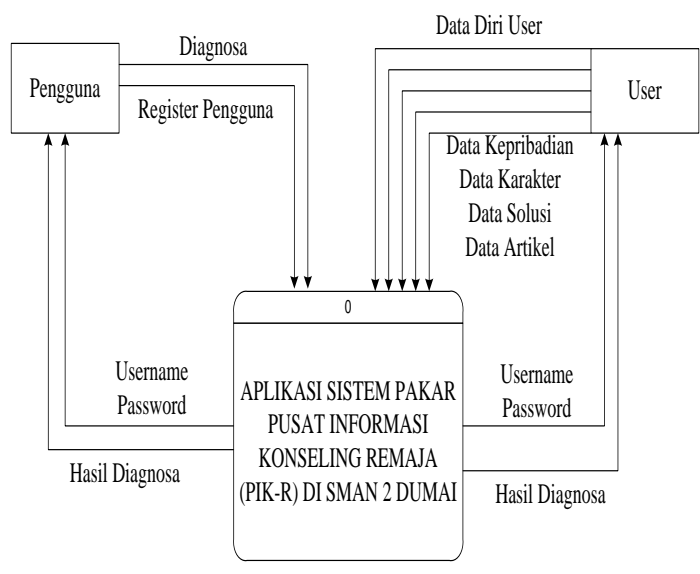

Gambar. 6. Context Diagram

\section{Data Flow Diagram}

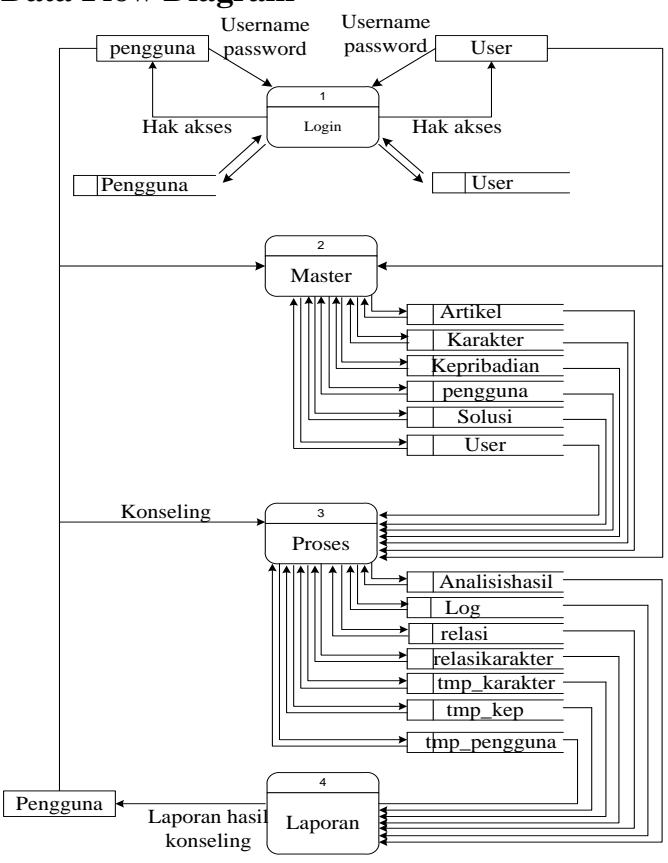

Gambar. 7. Data Flow Diagram

\section{Entity Relationship Diagram (ERD)}

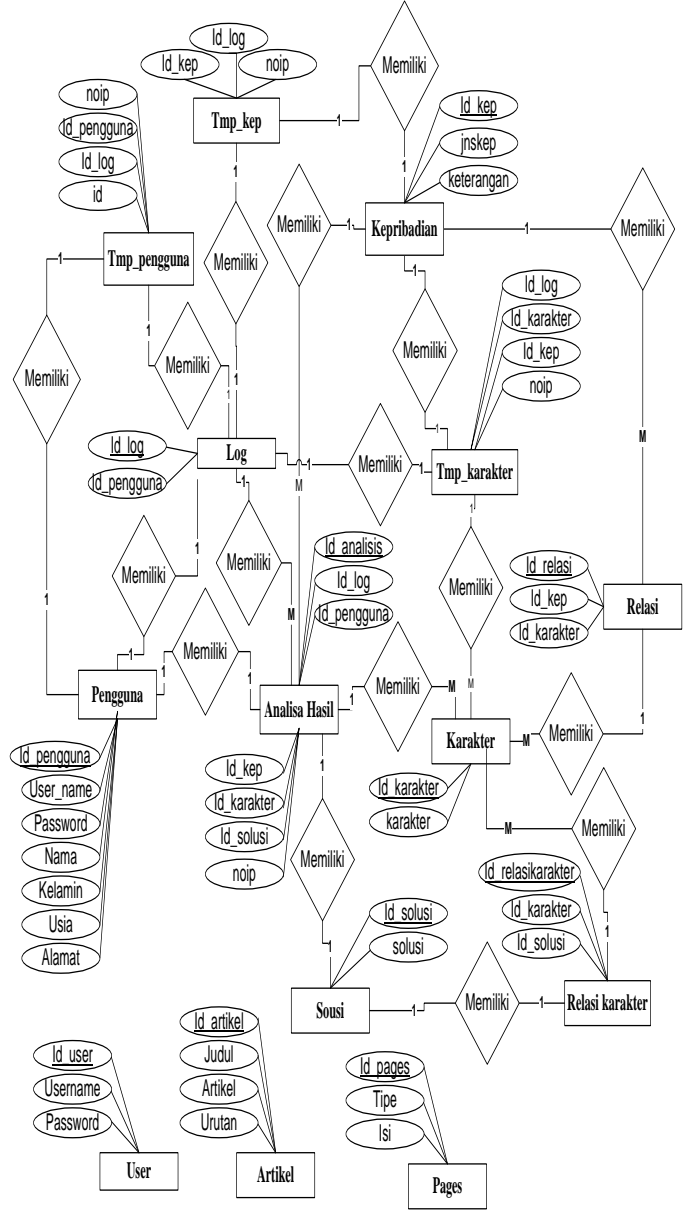

Gambar. 8. Entity Relationship Diagram

\section{Struktur Program (HIPO)}

a. Hierarkhi Input Proses Output Login Pengguna

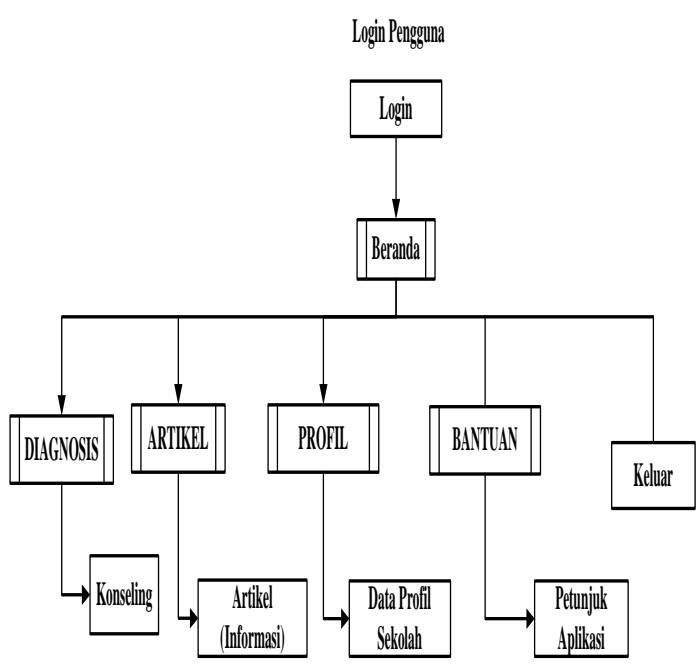

Gambar. 9. HIPO Login Pengguna 
IN F ORM A I K A

Jurnal Informatika, Manajemen dan Komputer, Vol. 10, No. 2, Desember 2018 eISSN : 2580-3042

pISSN : 1979-0694

b. Hierarkhi Input Proses Output Login Admin

b. Flowchart Input Data Admin

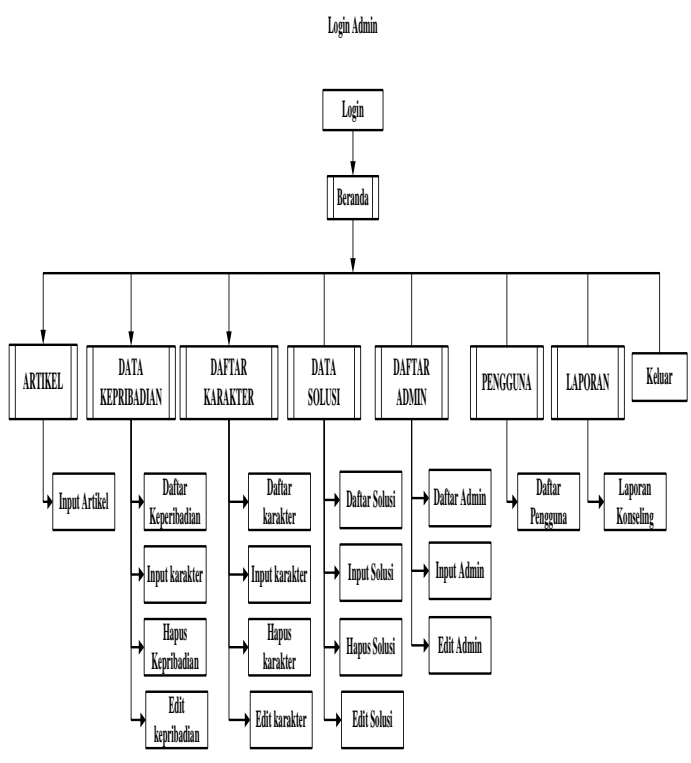

Gambar. 10. HIPO Login Admin

1. Permodelan Logika dan Algoritma (Flowchart)

a. Flowchart Login

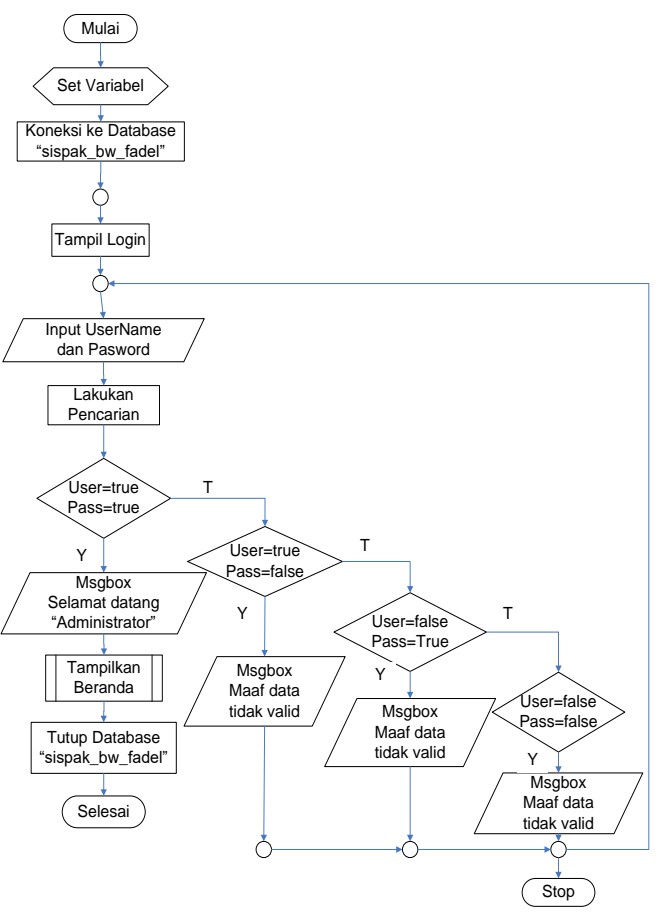

Gambar. 11. Flowchart Login

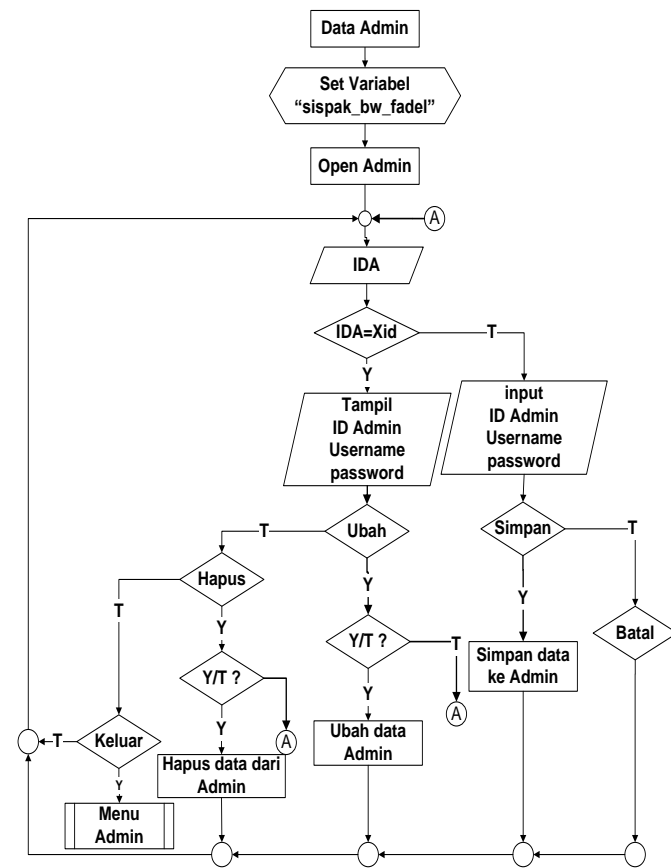

Gambar. 12. Flowchart Input Admin

c. Flowchart Proses Metode Backward Chaining

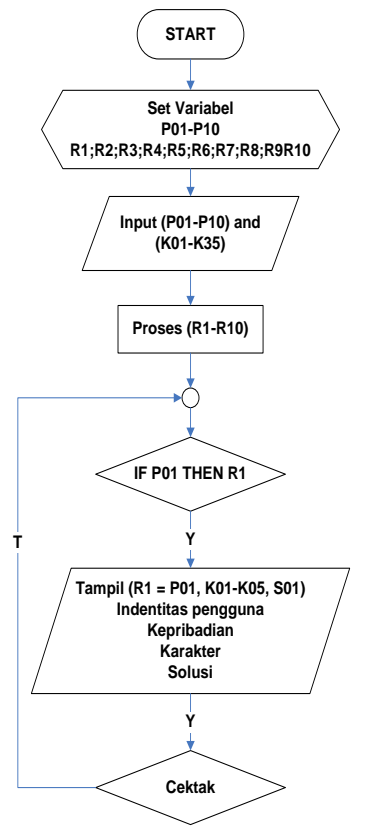

Gambar. 13. Flowchart Metode Backward Chaining 
I N F O R M A T I K

Jurnal Informatika, Manajemen dan Komputer, Vol. 10, No. 2, Desember 2018

eISSN : 2580-3042

pISSN : 1979-0694

e. Implementasi Program

a. Tampilan Awal Program

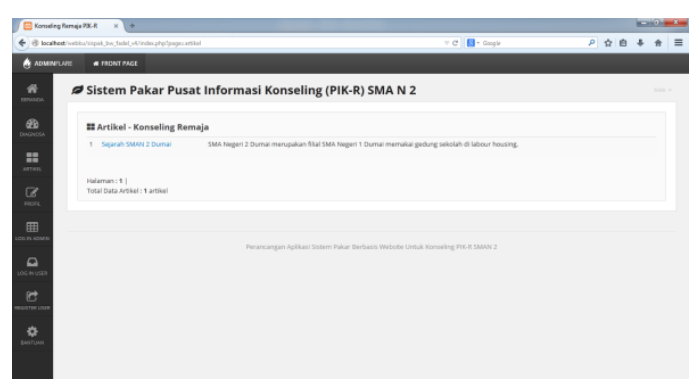

Gambar.14. Tampilan Awal

1. Tampilan awal program lakukan pilih login user untuk melakukan diagnosa kepribadian.

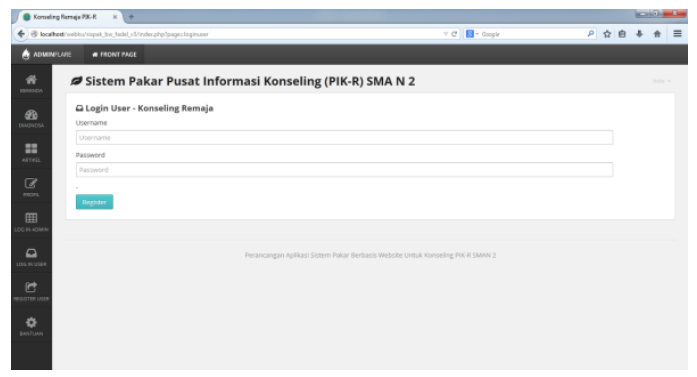

Gambar.15. Tampilan Login User

b. Proses Konseling

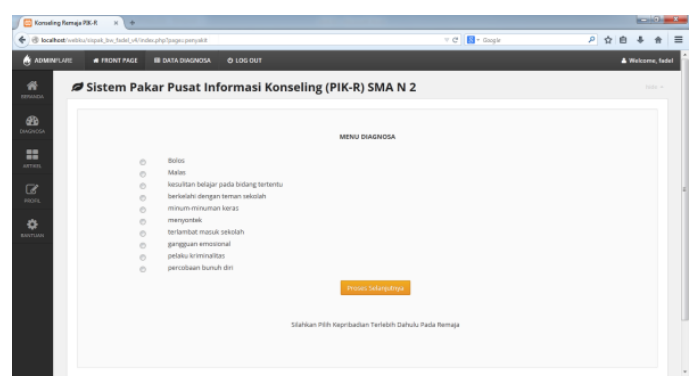

Gambar. 16. Proses Konseling pemilihan kepribadian

1. Pemilihan Kepribadian yang ingin kita deteksi

2. Lalu tekan tombol proses untuk melakukan proses selanjutnya.

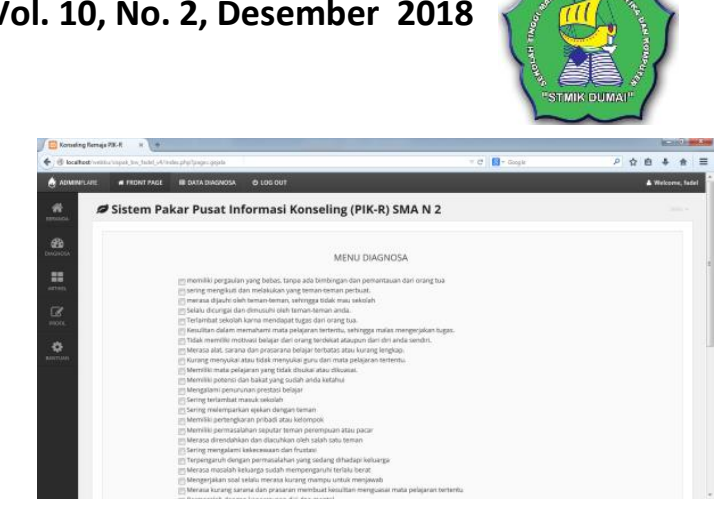

Gambar. 17. Proses Konseling Proses Pemilihan Karakter

3. Lalu pilih karakter sesuai dengan apa yang anda rasakan dalam diri anda.

4. Lalu klik tombol proses kembali pada bagian bawah halaman, untuk mendapatkanhasil konseling.

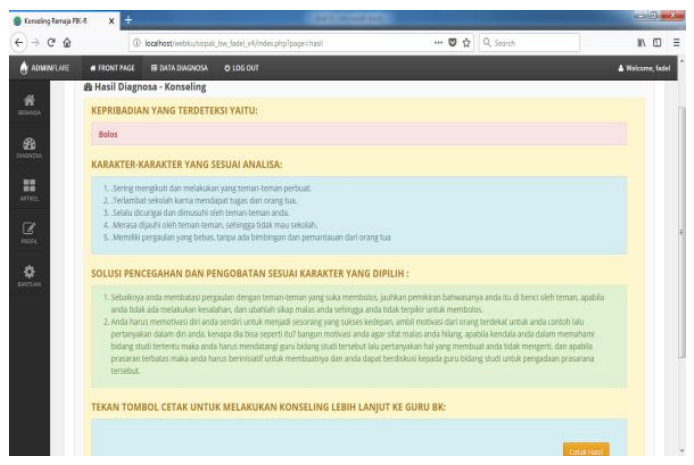

Gambar. 18. Hasil Diagnosa Konseling

\section{KESIMPULAN}

Berdasarkan penelitian yang telah dilakukan dengan mengamati dan menganalisa sistem konseling yang dilakukan serta dilandasi oleh teori-teori dan metode-metode serta didukung dengan alat-alat yang digunakan berkaitan dengan penelitian. Maka dapat disimpulkan bahwa untuk menerapkan sistem komputer dengan menggunakan suatu paket aplikasi komputer. Yang mana nantinya dapat menggantikan sistem lama yang ditangani secara manual. Maka berdasarkan uraian-uraian di atas, maka dapat diambil beberapa kesimpulan :

1. Dengan menggunakan sistem yang telah terkomputerisasi maka, dapat mempermudah dalam melakukan konseling tanpa memikirkan kapan guru BK memeiliki waktu kosong.

2. Mengolah data, penyimpanan data, penggunaan dan pemanggilan data dapat dilakukan secara cepat, tepat dan akurat karena menggunakan sistem database yang terstruktur dan terpusat.

3. Tingkat keamanan lebih terjamin dikarenakan data konseing hanya siswa 
IN F ORM A T IK A

Jurnal Informatika, Manajemen dan Komputer, Vol. 10, No. 2, Desember 2018

eISSN : 2580-3042

pISSN : 1979-0694

yang tau maslaah apa yang sedang dihadapinya, dan apabila dia ingin melakukan konseling lebih lanjut dia tinggal mencetak hasil konseling. Dan memintak pendapat kepada guru BK.

\section{REFERENSI}

Dahlan, M. (2013). Cara mudah membuat Web PHP. Bekasi: CV. Nusa Agung.

Elisawati. (2017). Sistem Deteksi Objek Dengan Menggunakan Sensor Ultrasonik Berbasis Fuzzy. Jurnal Informatika, Manajemen Dan Komputer, 9(1), 10-14. Retrieved from http://www.ejournal.stmikdumai.ac.id/ind ex.php/path/article/view/58

Ismael. (2017). Rancang Bangun Sistem Informasi Penyaluran Semen Padang Untuk Daerah Bengkulu Selatan Di Cv. Mutia Bersaudara. Jurnal Edikinformatika, 2(2), 147-156.

Iswandy, E. (2015). Sistem Penunjang Keputusan Untuk Menentukan Penerimaan Mahasiswa Dan Pelajar Kurang Mampu, 3(2).

Kusbianto, D. (2010). Analisis Dan Perancangan Sistem Informasi. (Bangil, pp. 1-140).

Mujilahwati, S. (2014). Diagnosa Penyakit Tanaman Hias Mengunakan Metode Certainty Factor Berbasis Web. Jurnal Teknika, 6(2), 585-591.

Noor, A., \& Saw, M. (2016). Aplikasi Kisah 25 Nabi Dan Rasul Berbasis Android, 2.

Nur, A., Ikhsan, D., Ariadi, I., Rosyid, M. B., \& Ridwan, M. (2017). Perancangan Sistem Pakar Menggunakan Metode Backward Chaining Untuk Diagnosa Penyakit Pada Hewan Ternak Sapi Berbasis Web, 19-24.

Oktaviani, T. W., Widyawan, \& Hantono, B. S. (2014). Perancangan User Interface Berbasis Web Untuk Home Automation Gateway Yang Berbasis IQRF TR53B. Seminar Nasional Teknologi Informasi Dan Komunikasi, (Sentika), 271-278.

Rachman, A. N., Gufroni, A. I., Hiron, N., \& Rahmayati, G. (2013). Analisis Perbandingan Performansi dan Pemilihan 